\title{
Gender, Traditionalism, and Attitudes Toward Domestic Violence Within a Closed Community
}

\author{
Efrat Shoham
}

\begin{abstract}
This research was aimed at examining the attitudes toward domestic violence of people living in communal secular and religious kibbutzim. The findings, disregarding gender or traditionalism, indicate that most of the kibbutz members examined view the kibbutz as almost totally lacking any problem of violence toward women by their partners. The belief that the kibbutz home is a secure place for women within the family framework appears, surprisingly, at a higher frequency among women than among men. There are two possible theoretical explanations for this finding. First, the kibbutz lifestyle has indeed brought about equal power relationships, which explains why domestic violence is not viewed as a social problem, mostly by secular women. Second, women, who play a relatively minor role in constructing the public agenda in the kibbutz, have not become aware of the existence of this issue in the closed community.
\end{abstract}

Keywords: gender; traditionalism; domestic violence; closed community

In Israel, violence among spouses is the most common violent crime, accounting for more than two thirds (68\%) of all violent crimes. Although the exact scope of violence against women within couples is not known, it is estimated that, out of the total population of $6,300,000$, there are about 200,000 battered women in Israel (Interoffice Committee on Domestic Violence, 2000). These women come from every socioeconomic level, profession, and ethnic background and include low-income and financially established women as well as uneducated and welleducated women (Lev-Ari \& Yairi, 1996).

In the past two decades, the public's awareness of domestic violence in Israel has grown and become a social problem that requires intensive intervention on the part of the Israeli criminal justice system, most particularly its law enforcement agencies (for a discussion of the growth of domestic violence into a social problem in Israel, see Abulafia, 1997). However, the internal organizations of the Kibbutz Movement, as a closed community within the Israeli society, have only recently begun to cope with this issue.

In 2000, a series of articles were published in the Israel national newspapers attesting to various occasions of violence and sexual attacks within kibbutz families (Vegshal, 2002). At the end of 2002, a conference on the subject of violence and sexual assault was held by the Kibbutz Movement. Upon conclusion of the

International Journal of Offender Therapy and Comparative Criminology, 49(4), 2005 427-449 DOI: $10.1177 / 0306624 X 04274102$

(C) 2005 Sage Publications 
conference there was a call for the creation of a working group to study the phenomenon, to create a moral-public position on the subject, and to indicate approaches and manners to deal with this subject. Although organizations were created to assist these battered women in the kibbutz, no empirical data that could describe the phenomenon were collected. With that in mind, from interviews with heads of such organizations it was clear that these were not a few sporadic instances within the kibbutz society but rather an ongoing occurrence that was widespread and required the action and intervention of kibbutz institutions to prevent such attacks and to educate on the phenomenon (Vegshal, 2002). During 2003, a telephone hotline was created to assist women experiencing violent and sexual attacks within the kibbutz community. The founding belief behind the creation of the hotline was that the percentage of women on the kibbutz experiencing domestic violence was the same as the percentage of women in the Israeli society (A. Leshem, personal communication, May 3, 2003).

Within the first half of 2003, the members of a kibbutz in the northern part of Israel voted to strip the membership from a kibbutz member found guilty of assault, battery, and threats to his wife. The kibbutz member turned to court to have the kibbutz's decision appealed, and the court found that the kibbutz had no ground for stripping him of his membership even if he was found guilty of assaulting his wife. According to the judge who sat in this case, the kibbutz member's violent attack against his partner was not sufficient to determine if his moral fiber was appropriate to those of the kibbutz or its members, nor did the kibbutz constitution, which acts as a formal guide for kibbutz life, rule or set out guidelines in regard to family violence (Gilboa, 2001).

This research attempted to examine how kibbutz members perceive domestic violence and to compare the stands and opinions of secular kibbutz communities to those of religious kibbutz communities.

\section{THE KIBBUTZ AS A CLOSED COMMUNITY}

For years, the kibbutz community in Israel has functioned as a closed community distinct from other communities by clear physical, cultural, and social boundaries. As a community, the kibbutz has a separate system of norms and social definitions different than that of communities in the general society. Life within the kibbutz community is characterized by a code known mainly to members of the community, by internal supervising mechanisms, and by controlled contact with surrounding society. For instance, the kibbutz is a semidemocratic society with a series of hierarchical organizations that decide and plan the long-term objectives as well as manage the daily life of the kibbutz. The General Members Assembly is the ruling organization above all other kibbutz institutions, and the kibbutz secretary and the other elected committees are smaller organizations responsible for the daily management of the kibbutz. It should be noted that not all of the decisions made by these organizations are brought to the attention of the kibbutz members in general. 
For many years, the kibbutz community defined itself as an egalitarian, communal community that identified with working for the good of the whole community and not for the individual. As the kibbutz is primarily a closed community, it activates internal supervising mechanisms that are, however, most powerful in creating a high inner commitment and solidarity toward the system of values and norms (Ben-Rafael, 1996; Sheffer \& Shapira, 1992). The kibbutz was founded on the concept of equality among members who possessed a strong inner commitment to the kibbutz ideology. This strong ideology promoted an informal supervisory system (Rosner, Glick, \& Goldenberg, 1993) whose structural closeness along with the strong ideology created a so-called code of silence (Eilam, 1995) regarding the frequency or the characteristics of deviant and/or violent behavior (for a description of the coping methods used by kibbutz societies in handling criminal activities within the kibbutz, see Shoham, 1995).

Since the 1980s, many cultural and organizational changes have been seen within this society. As a result of the social and economic crisis that the kibbutz, particular the secular one, has undergone since the early 1980s, and as a result of the processes of individualization and privatization that accompanied the crisis, the boundaries have been lowered, and the differences between the kibbutz and its social surroundings have lessened (Rosalio, 1993). The kibbutz has had to redefine which deviant behaviors are threatening to the kibbutz and, in view of the weakening of the traditional supervising systems in the kibbutz, what is the most suitable way to deal with these behaviors (Shoham, 1995). However, these processes of change do not occur at an equal rate in the various types of kibbutz; the economical and social crisis that has led to a significant change in the lifestyles of the secular kibbutz toward the end of the 1990s had less of an effect on the religious kibbutz system. The religious kibbutz continues to preserve, to a large extent, the characteristics of a closed community that possesses a communal, religious ideology and internal supervising and judicial systems.

\section{SOCIAL SUPERVISION WITHIN THE RELIGIOUS KIBBUTZ}

As stated above, to a large extent, the economic and social crisis that characterized the secular kibbutz movement of the 1990s skipped over religious kibbutzim (Ben-Rafael, 1996). Despite considerable structural-organizational similarities between religious and secular kibbutzim, the religious kibbutz continues to preserve control mechanisms meant to regulate interaction with secular society and cultural and social barriers that characterize any kibbutz community. Internal judicial and supervising systems are based on the strong commitment of members of the religious community to the system of norms that characterize the group. Kanter (1972) states that within the religious commune a person's obligation is simultaneously supposed to include diverse areas including human relationships within the community, education, organization of public life, the ideological, religious, and communal value systems, and so on. The individual is committed simultaneously to both religious values and the social norms of the religious com- 
munity. The broader the commitment, the more it is strengthened along with the individual's sense of belonging to the community (Cullen, 1994; Hakins, Artur, \& Catalano, 1995).

This feeling of belonging and solidarity is what stands behind the almost exclusive use of internal supervision mechanisms that are meant, above all, to preserve the religious and collective character of the community. It could be said that the religious value system, which is practically unchanging, to a large extent preserves traditional sex-role division and moderates many of the changes that occur within secular kibbutz society. In comparison with the secular kibbutz, the value of family is a central to the religious kibbutz society, and thus the family unit has suffered no real challenge, nor has the woman's traditional role been disturbed within the religious kibbutz (Avivi, 1999).

\section{FAMILY AND WOMEN IN THE SECULAR KIBBUTZ}

The secular kibbutz society has undergone many changes in its perception of the family's role within the life of the community. During the first half of the 20th century, the secular kibbutz, unlike the religious kibbutz, perceived the family as a competing factor for the individual's loyalty to the general social framework and for the individual's willingness and ability to invest time and energy in the tasks for the collective (Fogel-Biaggi, Sheffer, \& Shapira, 1992). Over time, interaction among the family, the kibbutz, and its communal institutions changed. The family became an important and fundamental factor in kibbutz society. With the strengthening of the processes of individualization and privatization came a weakening of the power of the communal kibbutz institutes, and family autonomy, as a private unit, increased in matters of education, consumption, and economics (Ben-Rafael, 1996).

One of the interesting questions raised by the major changes in the kibbutz social order regards the women's role. The rapid institutionalizing of the secular kibbutz changed the kibbutz structure from a nonfamilial structure to a very powerful familial structure (Spiro, 1983). During this process, women have largely returned to traditional female roles of childrearing, laundry, and cooking. A main feature of kibbutz life was the children's homes where, from infancy, children lived in communal homes with their peers and visited with their parents every evening. The staff in the children's homes was all female, and women were also those who did the kitchen and laundry work, whereas men performed agricultural work and later on, with the development of kibbutz industries, industrial and managerial work. This division brought about a gradual departure of women from the central public arena where the issues discussed were those of which women were less knowledgeable and competent than men. Thus, women were actually dispossessed from the running of the political economy of the kibbutz, which was left entirely in male hands (Ben-Rafael, 1996). With the relegation of women to a lower social status because their work did not produce income, women assumed a strategy of returning the power of the family as a substitute for social status. In the 
1980s, a transition began from the traditional kibbutz children's home to a system whereby children lived with their parents. This, in addition to the privatization of consumption (i.e., members were given an allowance to spend according to their priorities, and they no longer had their needs dictated and provided by the kibbutz) greatly contributed to the empowering of the family unit and to the transfer of most of the responsibility for the family unit to the woman.

Although the kibbutz as a revolutionary social framework liberated women from economic dependence on men and even provided mutual services that exempted women from their traditional roles in the home, many researchers who have studied the kibbutz have concluded that the kibbutz has not been able to form a fundamental change in women's status in comparison with that of men, neither in employment nor in the managerial-organizational field (Fogel-Biaggi et al., 1992; Golan, 1961; Silver, 1984). Ben-Rafael (1996) explains that when addressing professional abilities and public managing ability, each sex sees the other sex in stereotypical eyes. In the kibbutz, specializing in what is known as productive (i.e., income-producing) work carries prestige higher than that given to those who work in areas connected to the family or to services for the benefit of the community. During a discussion regarding women's reactions to the changing kibbutz that was held in the mid-1990s, Palgi (1993), a sociologist researching women in kibbutz, stated that in her opinion women in the kibbutz feel like a marginal minority group, denied power and pushed out of the public arena, lacking any control over economic resources. Shoham (1995) found that in those kibbutz societies in crisis, women feel detached and alienated from the formal institutionalized activity that is now forming the changing kibbutz.

The description of the woman's role within the secular kibbutz society brings us to a discussion on the claim that the kibbutz society is somewhat a dichotomy. On one hand, the kibbutz ideological reports to support equality between men and women, yet on the other hand on a daily basis the women's role in a secular kibbutz is no different than that of a women in a religious kibbutz. Therefore, within the secular kibbutz the woman's position is weakened in comparison to that of man's. The lesser position of women in a kibbutz society also brings us to assume that the social agenda and the decision of what is important to the kibbutz society is left strictly in the men's hands (for a discussion of a similar phenomenon in the general Israeli population, see Kamir, 2002).

\section{VIOLENCE BETWEEN SPOUSES AS A SOCIAL PROBLEM IN THE KIBBUTZ}

A situation is defined as a social problem when the public becomes aware of the threat only after the situation compromises the public's basic social values (Becker, 1966). To a large extent, this definition is a result of power relations within a given society, where all parties want to establish the dominance of their worldview and strengthen it with definitions that strengthen their interests in the process (Gusfield, 1981). 
Describing a social problem as a result of political-social power struggles can explain why a specific phenomenon is defined as a social problem in a certain society in a certain period of time, whereas it is not defined as such elsewhere and in another time. Since the 1980s, increased awareness and public activity regarding the question of violence within couples have greatly changed Israeli society's definitions of violence against women. Such violence has changed from being viewed as a familial and private matter to being a social and public problem (Abulafia, 1997). This change in definition has resulted in stronger enforcement and in somewhat harsher punishment of violent offences within couples (Shoham, 2000; Shoham \& Abulafia, in press).

These changes have not been felt within the kibbutz society, which until the end of the 1990s continued to view family violence as a one-time, private matter that did not require the intervention of kibbutz organizations and that therefore did not necessitate any special organization within the kibbutz. When cases of deviation or violence reach kibbutz public awareness, these behaviors are perceived in the kibbutz as being diametrically opposed to the system of values and norms upon which kibbutz society is based (Shoham, 1995). One technique used to overcome this contradictory construct was to combine three mechanisms: avoidance, denial, and rationalization (Eilam, 1995). These mechanisms, which produce a type of negative deployment, assist the kibbutz in avoiding dealing with social issues that in their very essence contradict the symbols and definitions that are basic to the kibbutz entity. Negative deployment describes the total lack of open institutional discussion or activity regarding cases of domestic violence.

The fact that the kibbutz did not prepare itself to deal with deviant behaviors strengthened the perception among kibbutz members that the kibbutz is in many ways immune, safe from behaviors such as theft, rape, assault, domestic violence, or murder (Shoham, 1996). As mentioned in the introduction, the Kibbutz Movement found itself unprepared to explain to members how violent and sexual assaults were occurring within the family structure of its elite society.

\section{A PERCEPTION OF AN ELITE SOCIETY}

The kibbutz society attempted to perpetuate the image of an elite society through the technique of defensive attribute (for more information, see Shaver, 1970). This technique characterizes situations where a group of people or individuals perceive themselves as being potentially threatened because of their way of life or beliefs. Defensive attribute is based on the finding of a causal explanation for the deviant behavior by attributing the deviance to specific characteristics that are personally related to the victim, the offender, or the situation (Kristiansen \& Giulietti, 1990; Sugerman, 1994).

Kelly (1971) states that defensive attribution is a fast economic analysis of behavior because it acts as a framework in which different types of information are able to combine to arrive at a causal conclusion that will assist in understanding the result. The tendency to use defensive attributes grows, in Shaver's (1970) 
opinion, as those required to interpret the deviant event perceive themselves to bear greater similarity to the other. This defensive attribute enables avoiding potential guilt and damage to one's personal and social self-perception.

Presenting the victim or the offender as essentially different from other group members helps minimize the threat of potential guilt that accompanies similarity to the offender (Drout \& Gaertner, 1994; Kristiansen \& Giulietti, 1990). Generally, the more the group feels threatened and must protect its common features, its cultural definitions, or its systems of law and norms the more we will expect to find a higher use of defensive attribute techniques (Shoham, 1996). This technique helps preserve a current world of cultural symbols as right and just, it arouses feelings of control over events, and it seemingly avoids situations of potential guilt or victimization.

The paucity of research that examines attitudes toward the crime of violence toward women by their partners in the general public, and specifically in closed communities, was what led us, in the present project, to examine the attitudes of members of the kibbutz society, secular and religious, men and women, about violence toward women by their partners.

Our hypothesis is that the greater the degree to which a community is closed and the greater the amount of pressure that is activated on its members toward high inner solidarity the lower the tendency to view violence between partners as a general social problem will be. This tendency is expected, in our opinion, to bring about a higher rate of specific explanations that locate the cause of violence within the specific characteristics of the criminal or the victim. These explanations, as stated, enable one to distance the source of the deviance from the normative or cultural characteristics of the closed community to which they are committed and enable the attribution to the personal qualities of the persons involved in the deviant and/or violent behavior.

The closed character of the religious kibbutz community as compared to the secular one and the relative detachment of women in the kibbutz from positions of economic and social power bring us to the assumption that the tendency to prefer external supervising systems such as the police to deal with violence within couples is higher among members of the secular kibbutz than among members of the religious kibbutz, and that because women in the kibbutz feel less committed to the kibbutz value system, they are more supportive of involving external supervising systems for the treatment of this crime than are men.

\section{METHOD}

Four kibbutzim of medium size (having more than 150 members) located within the geographic center of the country were chosen for this research. Two of the kibbutzim belong to the religious kibbutz movement, and the other two belong to the United Kibbutz Movement, which is a secular association. All four of the kibbutzim were similar in terms of size, location, years of existence, and eco- 
nomic situation; each are over 40 years old and are defined as being in a moderate financial state. In each kibbutz, a systematic random sample was taken from the list of current members, using a random number table. Out of this list, approximately $20 \%$ of the members of each kibbutz were sampled, for a total of 140 questionnaires sent.

To allow for the anonymity of the respondents, we placed the questionnaire in the members' mailboxes. The questionnaire was placed in a closed envelope with another stamped envelope with the address of the researcher. The questionnaire was accompanied by a letter explaining and describing the research, the researcher's professional background, the objective of the study, and the methodology used in choosing the respondents. The kibbutz members were requested to answer the questionnaire on their own and to return it to the address on the envelope. In addition, complete anonymity was promised; it was explained that the information from the questionnaire was for research only. This procedure was designated to minimize the possible bias related to participants' wariness of handing the questionnaires to a kibbutz member they know. The drawback of this method is that many participants may fail to return the questionnaire, thus damaging its external validity (Weisburd \& Britt, 2003). Indeed, of the 140 questionnaires distributed, only 78 completed questionnaires were returned. It should be noted that although the selected kibbutzim have no unique features (e.g., border settlements, economic distress, or very small or very young characteristics), the relatively small number of kibbutz members who participated in the research might be an obstacle to generalizing the research findings.

Although only four kibbutzim of medium size from the center of the country were examined, we may note a great similarity in the processes of change taking place in kibbutzim nationwide (for a description of the change, see Ben-Rafael, 1996). The fact that only a little over half of the participants agreed to fill out the questionnaires and return them might hint that the lack of readiness to cooperate in such a sensitive issue, as this is felt even more so among the kibbutz members living within a closed community that is not eager to share its internal affairs with the outside world.

\section{PARTICIPANTS}

Of the 78 questionnaires returned, 22 questionnaires were from men who define themselves as secular, and 20 were from women who define themselves as secular. Also, 17 were returned by men who define themselves as religious, and 19 came from women who define themselves as religious (all participants from the secular kibbutzim defined themselves as secular, and all participants from the religious kibbutzim defined themselves as religious). A total of $53 \%$ of all the participants were secular, and $47 \%$ were religious. The youngest participant was 21 years old, and the oldest was 73 . The average age of participants was 38 ( $S D=$ 13.9). As for marital status, $28 \%$ of all participants were single, $66 \%$ were married, and $6 \%$ were divorced. Over half (54\%) were high school graduates, $40 \%$ 
had a full or partial bachelor's degree, and 6\% did not complete 12 years of education. Also, $38 \%$ described themselves as socially active, $40 \%$ were born on the kibbutz, $42 \%$ were born in a town, and $18 \%$ in a moshav (farming village).

A comparison of religious kibbutz members to members of the secular kibbutz yielded no significant differences in the distribution of age or level of education. In addition, no significant differences in the distribution of place of birth or the extent of involvement in the social activity on the kibbutz. Even so, more secular kibbutz members $(45 \%)$ reported a higher involvement in social roles than did the religious kibbutz members $(30 \%)$.

\section{RESEARCH TOOLS}

Data were collected using a Likert-type attitude questionnaire consisting of 46 statements to which responses range from strongly agree to do not agree at all. The questionnaire, designed by the researcher, was partially based upon existing questionnaires on the issue of attitudes regarding violent felonies between partners (Izkovitz \& Gripel, 1998; Shoham, 2000) and partially upon questions that were adapted to the kibbutz reality. The questionnaire consists of three scales that were each checked for internal consistency using Cronbach's $\alpha$ coefficient. The first part, consisting of 19 statements, relates to the question of awareness of the existence of the problem generally and specifically in the kibbutz (Cronbach's $\alpha=$ 0.68). This part consists of three subscales addressing three areas (internal consistency of each subscale was measured using Cronbach's $\alpha$ ). The first subscale measures the rate of violence in Israeli society as perceived by kibbutz members $(\alpha=0.68)$. The second subscale relates violence within a couple to an urban lifestyle $(\alpha=0.74)$. The third subscale measures the rate of violence within couples on a kibbutz as perceived by kibbutz members $(\alpha=0.63)$.

The second part consists of eight statements that describe different explanations for a man's violence toward his female partner. This part consists of statements such as, "Violent men are usually drunks or drug addicts," "A man who hits his wife has mental disorders," "Poverty causes violence within couples," "Violence within a family is related to personal factors and not to power relationships between sexes," "A man who beats usually has seen his father hit his mother," "The woman, in her behavior, causes the beating," and "Only women who are not mentally healthy would stay with a man who beats."

The third part of the questionnaire also consists of 19 statements that refer to the preferred social reaction of kibbutz members in dealing with the violent felonies between partners (Cronbach's $\alpha=0.67$ ). This part is also divided into three subscales. The first subscale measures preference to internal supervision over external supervision in cases of violence of men toward their partners $(\alpha=0.71)$. The second subscale measures preference to punitive rather than therapeutic reaction in cases of violence toward women $(\alpha=0.78)$. The third subscale measures interference or secrecy in cases of violence toward women within the family $(\alpha=$ $0.63)$. 
TABLE 1

VIOLENCE TOWARD WOMEN AS A SOCIAL PROBLEM

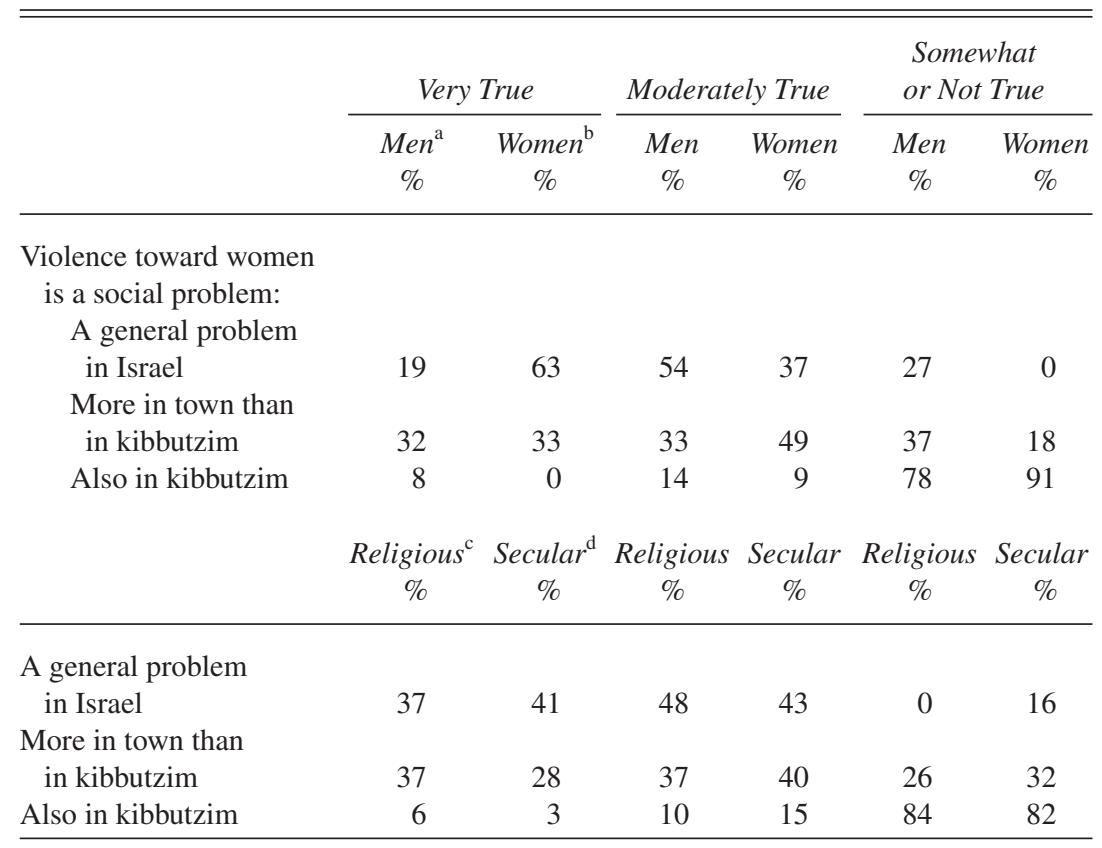

a. $n=39$.

b. $n=39$.

c. $n=36$.

d. $n=42$.

\section{RESULTS}

The first question we wished to examine was whether kibbutz members perceived violence between partners as a social problem. Table 1 presents the degree of agreement that men and women, secular and religious, express regarding the perception of violence between partners as a nationwide social problem, particularly in the kibbutz.

As seen in Table 1, 63\% of the women in the sample believe that violence toward women by their partner is a highly common social problem in Israel, compared to $19 \%$ of the men who believe this. Both types of kibbutzim related similarly to violence toward women as a social problem: $85 \%$ of the secular kibbutz members and $84 \%$ of the religious kibbutz members believe that violence toward women in Israeli society is a highly common or moderately common social problem in Israeli society.

The claim that violence toward women is much more common in the town as compared with the kibbutz is agreed with surprisingly more among the women 
sampled. Compared with $18 \%$ of the women who do not agree with this, more than one third of the men $(37 \%)$ do not think that there is more violence in town than in the kibbutz. There is no difference in the percentage of supporters for this claim between the religious kibbutz members and the secular. About two thirds of the religious and secular kibbutz members believe that violence toward women is more common in town than in the kibbutz. There are many fewer participants who are of the opinion that there is violence toward women in the kibbutzim: $22 \%$ of the men believe that there is violence against women in kibbutzim too, and only $9 \%$ of the women believe this. Almost no differences have been found between religious and secular members regarding this. Most of the participants (82-84\%) are of the opinion that there is hardly any violence toward women by their partners.

Table 2 presents the differences among the average agreement with the question with reference to gender and traditionalism. Table 2 reveals that there is a significant difference in the attitude of both genders about the issue of violence toward women as a widespread phenomenon in Israel, $F(1 / 78)=23 / 42, p<.00$. Mean agreement with this claim is significantly higher among women than among men. In the analysis of variance, no significant differences were found between members of the religious and secular kibbutzim, and no significant difference was found regarding the interaction between gender and type of kibbutz.

A significant difference between genders was also found in reference to the statement that violence is more common in town. The highest mean agreement was found among women, specifically among secular ones, $F(1 / 78)=7.40, p<$ .05 , but no significant interaction was found between gender and traditionalism and the support of the statement that violence toward women is more common in towns.

Analyses of variance show a significant difference between genders in supporting the statement that the kibbutz also has a problem of violence toward women by their partners, $F(1 / 78)=3056, p<.05$. Surprisingly, it is of higher frequency among men. Regarding this question, there was a significant interaction among gander, traditionalism, and the degree of support for this statement, $F(1 /$ $78)=5.05, p<.05$.

\section{HOW IS VIOLENCE BETWEEN PARTNERS EXPLAINED?}

To examine how kibbutz members explain the issue of violence toward women by their partners, we asked them to state their degree of agreement with a list of statements that express, as we have explained earlier, a continuum of public explanations. At the one end appear specific explanations that understand the reasons for the violence as related to the characteristics of the attacker and/or the victim, and at the other end are explanations that see the source of the violence within couples embedded in the social and cultural structure. Tables 3 and 4 present the degree of agreement among men, women, religious, and secular kibbutz members with the different types of explanations of why men hit their partners. 


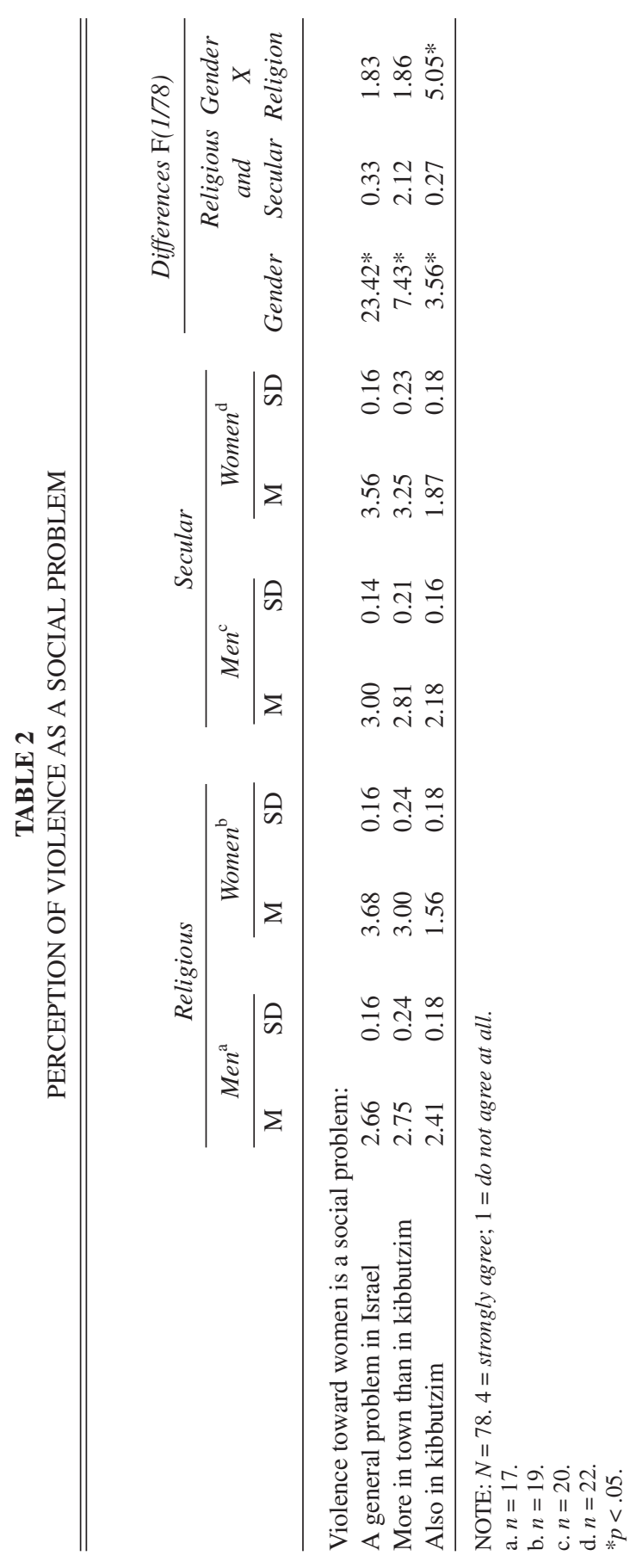


TABLE 3

PERCENTAGES OF AGREEMENT WITH EXPLANATIONS OF VIOLENCE

\begin{tabular}{|c|c|c|c|c|c|c|}
\hline & \multicolumn{2}{|c|}{ Very True } & \multicolumn{2}{|c|}{ Moderately True } & \multicolumn{2}{|c|}{$\begin{array}{l}\text { Somewhat } \\
\text { or Not True }\end{array}$} \\
\hline & $\begin{array}{c}\operatorname{Men}^{\mathrm{a}} \\
\%\end{array}$ & $\begin{array}{c}\text { Women }^{\mathrm{b}} \\
\%\end{array}$ & $\begin{array}{c}\text { Men } \\
\%\end{array}$ & $\begin{array}{c}\text { Women } \\
\%\end{array}$ & $\begin{array}{c}\text { Men } \\
\%\end{array}$ & $\begin{array}{c}\text { Women } \\
\%\end{array}$ \\
\hline $\begin{array}{l}\text { Men who hit have } \\
\text { mental problems }\end{array}$ & 91 & 83 & 6 & 3 & 3 & 14 \\
\hline $\begin{array}{l}\text { Violence is a result of } \\
\text { drug or alcohol abuse }\end{array}$ & 58 & 47 & 27 & 22 & 14 & 31 \\
\hline $\begin{array}{l}\text { Violence is a result of } \\
\text { economic distress }\end{array}$ & 59 & 50 & 19 & 30 & 22 & 20 \\
\hline $\begin{array}{l}\text { Violence is a result of } \\
\text { cultural norms }\end{array}$ & 76 & 80 & 21 & 24 & 3 & 6 \\
\hline $\begin{array}{l}\text { Violence is a result of } \\
\text { a personal problem }\end{array}$ & 78 & 75 & 10 & 12 & 12 & 13 \\
\hline $\begin{array}{l}\text { Violent men grew up } \\
\text { in violent homes }\end{array}$ & 76 & 46 & 6 & 38 & 18 & 16 \\
\hline $\begin{array}{l}\text { Women's behavior brings } \\
\text { violence against them }\end{array}$ & 9 & 14 & 15 & 22 & 76 & 64 \\
\hline & $\underset{\%}{\text { Religious }^{\mathrm{c}}}$ & $\begin{array}{l}\text { Secular } \\
\%\end{array}$ & $\begin{array}{c}\text { Religious } \\
\%\end{array}$ & $\begin{array}{c}\text { Secular } \\
\%\end{array}$ & $\begin{array}{l}\text { Religious } \\
\%\end{array}$ & $\begin{array}{c}\text { Secular } \\
\%\end{array}$ \\
\hline $\begin{array}{l}\text { Men who hit have } \\
\text { mental problems }\end{array}$ & 84 & 89 & 6 & 3 & 10 & 8 \\
\hline $\begin{array}{l}\text { Violence is a result of } \\
\text { drug or alcohol abuse }\end{array}$ & 48 & 59 & 27 & 23 & 25 & 18 \\
\hline $\begin{array}{l}\text { Violence is a result } \\
\text { of economic distress }\end{array}$ & 63 & 45 & 19 & 30 & 18 & 25 \\
\hline $\begin{array}{l}\text { Violence is a result of } \\
\text { cultural norms }\end{array}$ & 70 & 51 & 11 & 39 & 19 & 10 \\
\hline $\begin{array}{l}\text { Violence is a result of } \\
\text { a personal problem }\end{array}$ & 87 & 65 & 5 & 18 & 8 & 17 \\
\hline $\begin{array}{l}\text { Violent men grew up } \\
\text { in violent homes }\end{array}$ & 44 & 73 & 28 & 19 & 28 & 8 \\
\hline $\begin{array}{l}\text { Women's behavior brings } \\
\text { violence against them }\end{array}$ & 9 & 13 & 21 & 16 & 70 & 71 \\
\hline $\begin{array}{l}\text { Women who remain in an } \\
\text { abusive home are not } \\
\text { mentally healthy }\end{array}$ & 19 & 19 & 40 & 43 & 41 & 38 \\
\hline
\end{tabular}

NOTE: $N=78$.

a. $n=39$.

b. $n=39$.

c. $n=36$.

d. $n=42$. 


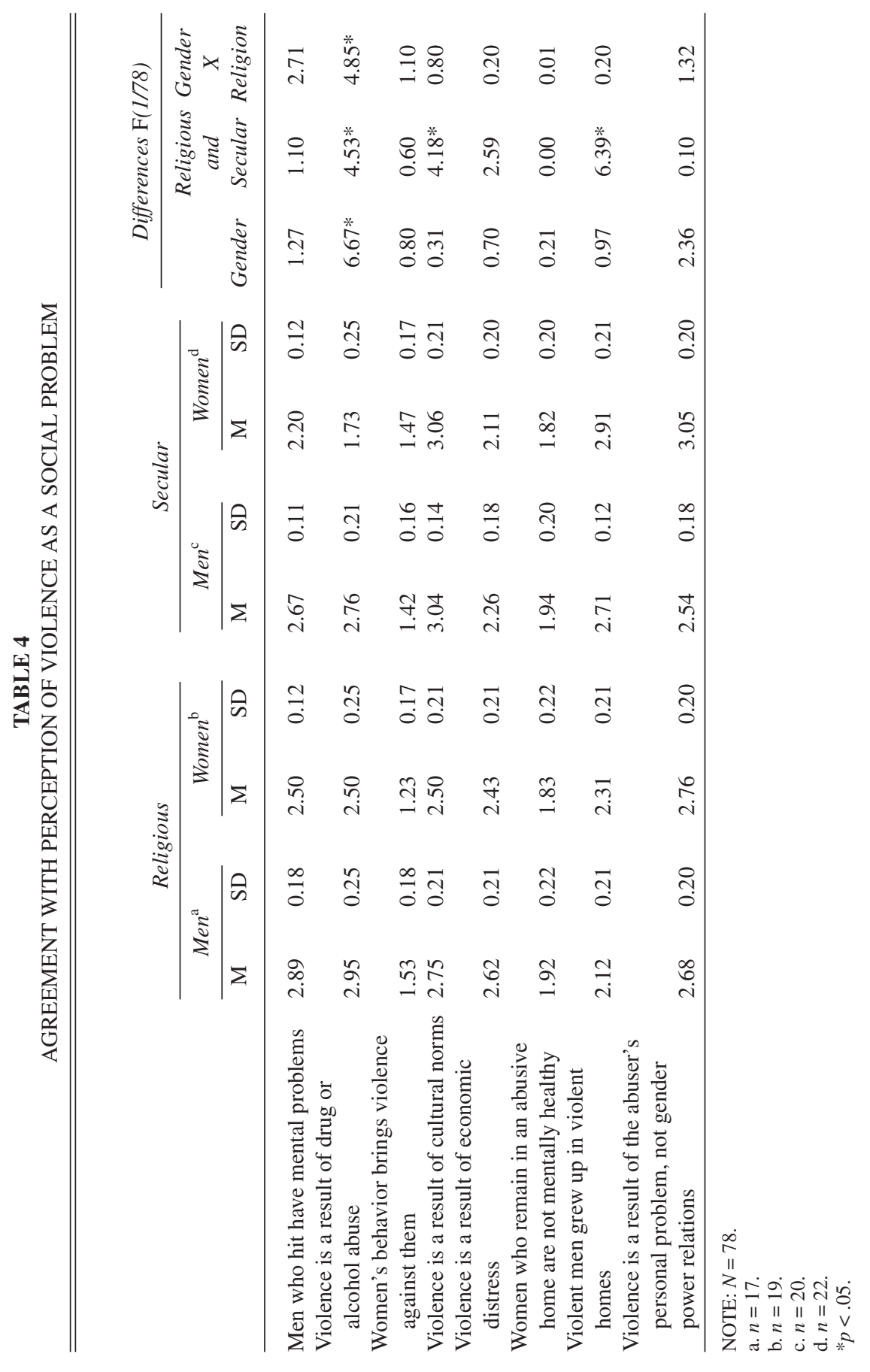


The most common explanation for violence against women by their partners was the specific explanation that connects violence to various mental problems of the violent male partner. Regarding this explanation, no significant differences were found between sexes or type of kibbutz.

Most participants also believe that violence toward a woman by her partner derives from the violent partner's problems with drug or alcohol abuse. As seen in Table 3, attributing violence to the violent partner's drug and alcohol abuse is more common among men than among women and is more common among religious participants as compared to secular participants. As the analyses of variance show, there is a significant difference in this explanation in regard to gender as well as traditionalism. A significant interaction was found between gender and traditionalism and the perception of violence toward a woman as the result of drug and alcohol abuse of the attacker, $F(1 / 78)=4.85, p<.05$. Half of the men and women also believe that poverty causes violence within the family. This opinion is more common among men than among women and is more common among the secular participants than among religious participants, but no significant differences were found regarding gender or traditionalism.

One of the serious problems that accompanies violence within couples has to do with the difficulty society has in understanding the battered woman's decision not to involve external factors or break up the family even though she is the one who suffers violence, oftentimes severe. Indeed, about one fourth of the men and $15 \%$ of the women believe that women who stay with their violent partners are not mentally healthy. It should be emphasized that about one third of the participants, men and women, secular and religious, do not rule out the statement that claims that a woman's behavior brings the violence on herself. This explanation is more common among men than among women. Table 3 shows that most of the men and women in the sample do not support the feministic explanation (i.e., violence toward partners as an expression of the unequal power relations in society). They prefer to see violence as a behavior connected to a personal problem of the attacker or the attacked. It is interesting to note that the attribution of violence to a personal problem and not to an unequal social structure is more common among secular participants than among religious ones. The highest mean rate of agreement to this explanation was found among secular women. Despite this, Table 4 shows no significant differences in the mean rate of support regarding the gender or the traditionalism of the participants.

\section{HOW SHOULD ONE REACT TO VIOLENT EVENTS BETWEEN PARTNERS?}

In this part we asked the participants what the preferred reaction is to cases of violence toward women by their partners. As stated, we presume that characteristics of a closed society lead to preferring internal supervision over external supervision. 
TABLE 5 PREFERRED REACTION TO VIOLENCE AGAINST WOMEN

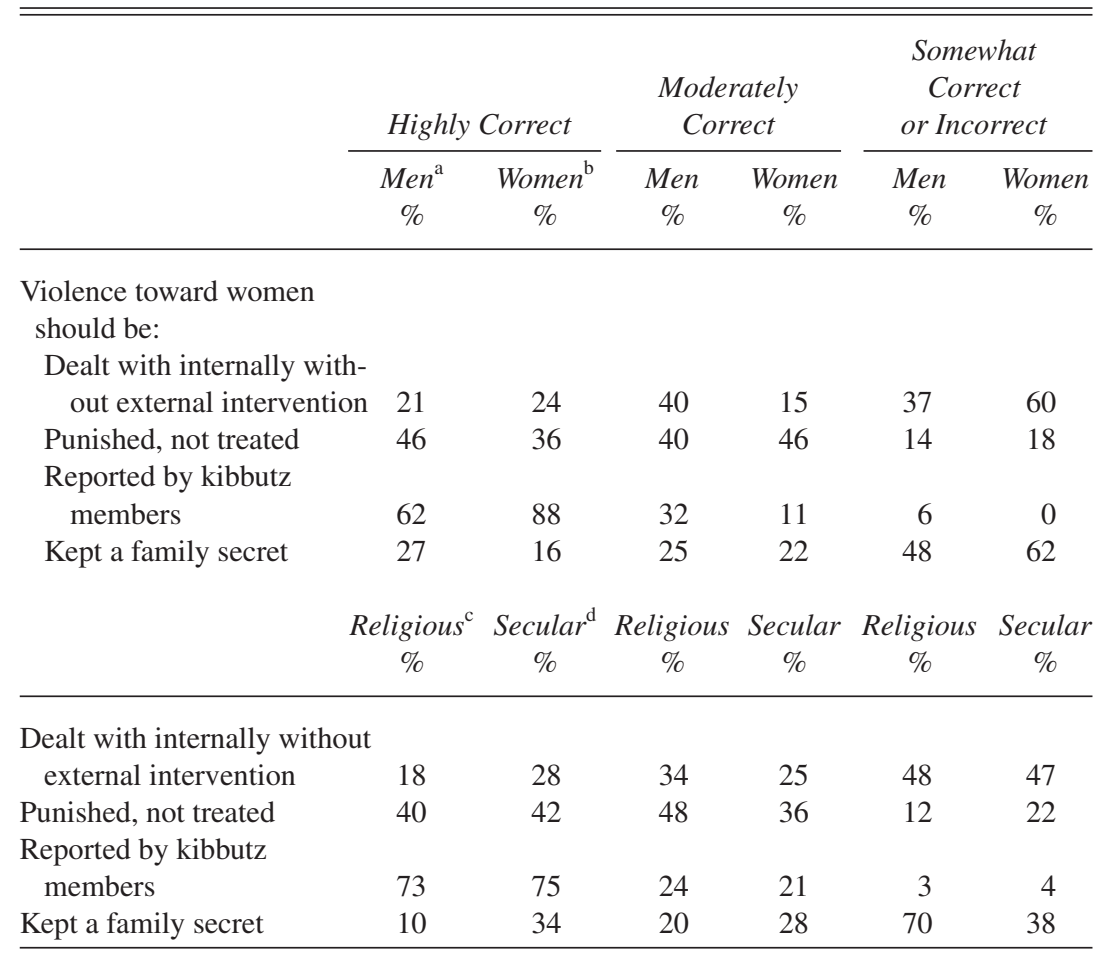

a. $n=39$.

b. $n=39$.

c. $n=36$.

d. $n=42$.

Tables 5 and 6 describe the type of supervision that is preferred among men and women, secular and religious. As seen in Table 5, over half the women (60\%) believe that dealing with violent events toward women should not be left to the kibbutz organizations, whereas $37 \%$ of the men support referring the issue to external authorities. In comparing the mean agreement between men and women with the claim that internal supervising institutes are preferable to the police, it seems that the higher support for this claim appears among the religious men and the lowest support appears among secular women. The multivariable analysis of variance shows a significant difference between the religious and the secular kibbutzim regarding this issue, $F(1 / 78)=4.75, p>.05$.

Table 5 also reveals that most of the secular people (70\%) do not agree that violence toward a woman in the family should be kept secret. This is in comparison to $38 \%$ of the religious participants who are opposed to keeping the issue a secret. 


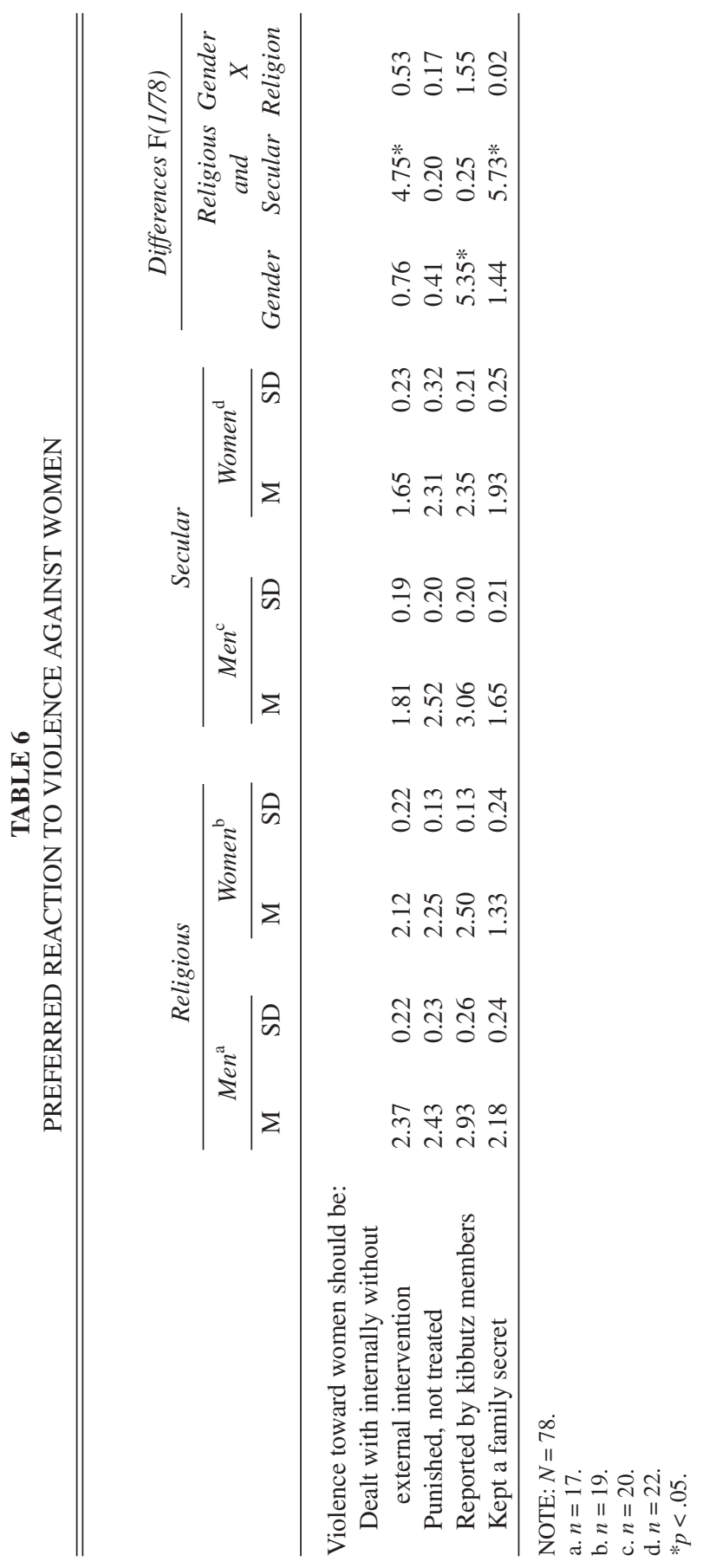


The highest support for keeping violence a secret was found among religious men (the lowest was found among religious women). The difference between religious and secular regarding this question is significant, $F(1 / 78)=5.37, p>.05$.

Regarding the question of a kibbutz member's personal obligation to report a violent event by a man against his partner, the women in the sample believe, more so than do the men, that the kibbutz member should report the event. The highest mean rate of agreement with the obligation to report was found among secular women. Table 6 reveals a significant difference on this issue between the sexes but not between religious and secular.

The analysis of multiple regression conducted to predict the position in the three areas shows that the participants' sociodemographic variables, such as education, marital status, or public activity involvement, are not significant predictors of perceiving violence toward women as a social problem, of the type of explanation used when referring to violence against women, or of the rate of support in the involvement of external supervising factors in the incidents of violence against women by their partners in the kibbutz.

\section{DISCUSSION}

This research was aimed at examining the attitudes of people living in a closed communal community, in this case the kibbutz, to violence toward women by their partners and the relation of this attitude to two variables: gender and traditionalism.

We sought to examine the differences in the way that male and female, religious and secular, kibbutz members perceive violence toward women within a couple, the way in which they explain it, and their preferred reaction in dealing with violence of this kind.

Our research hypothesis was that among religious kibbutz members we would discover a different reference to the issue of violence toward women in comparison to secular kibbutz members. We hypothesized that as the religious kibbutz continues to preserve, to a large extent, characteristics of a homogenous closed community with primary relationships, its members will prefer to perceive a husband's violence against his wife as a specific personal case and to deal with it using internal supervising mechanisms available to the community. In contrast, we hypothesized that the secular kibbutz, as part of the organizational and social processes of change that it is undergoing, will be more inclined to see the violence as belonging to a general social phenomenon and will prefer to have external supervising factors deal with it. We also hypothesized that as a result of the privatization process within the kibbutz and the relatively minor role in the shaping of the processes of change of women compared to men, women will be inclined to perceive internal supervising mechanisms as less effective or as irrelevant in dealing with the problem of violence toward women. 
The findings indicate that most of the kibbutz members examined, disregarding gender or traditionalism, view the kibbutz as almost totally lacking any problem of violence toward women by their partners. The belief that the kibbutz home is a secure place for women within the family framework appears, surprisingly, at a higher frequency among women than among men.

Our sample shows that although women in the kibbutz are more inclined than are men to perceive the issue of violence toward women by their partners as a common social problem in Israeli society, they perceive the problem of violence toward women as stopping at the threshold of the kibbutz and as not going beyond it. The women in the sample, especially the secular women, believe that violence toward women by their partners is widespread but that it occurs outside the kibbutz fence, and so it does not pose a problem for the members of the community living within it.

When we examined the type of explanations espoused by members of the kibbutz, it appeared that in contrast to the hypothesis most kibbutz members, regardless of gender or traditionalism, are inclined to see the violence of a man toward his partner as a result of his mental problems or of his drug and alcohol abuse. The general explanation that views violence toward women within the unequal politicalsocial order received little support among most of the participants. Interestingly enough, the feminist explanations (Chamallas, 1999; Mackinnon, 2001; West, 1997) that see violence as a symptom of the unequal power forces in society received the least support from the secular women.

There are two possible explanations for this finding. First, kibbutz lifestyle has indeed brought about equal power relationships, especially in the secular kibbutz, which explains why this explanation was rejected mostly by secular women. Second, as we have seen in the review of the literature (Blanc, 1995; Zamir, 1986), women, who play a relatively minor part in constructing the public agenda in the kibbutz, have not become aware of the existence of this issue as a social problem in the closed community.

Unlike women's organizations in Israel (Kamir, 2002), most of the women in this study adopt the specific explanations according to which violence between partners is not a symptom of a system of power relations between the sexes but a result of personal problems of a certain person. It is possible that as long as violence is perceived as alien to the values of the egalitarian kibbutz lifestyle there will arise the need to take on explanations of a defensive attribute type that help differentiate between the characteristics of the deviant and the characteristics of the ideological system where he came from (Larnner, 1980; Shaver, 1970). The defensive attribute explanation sees the attacked woman as a result of an urban lifestyle related to variables such as poverty or drug abuse or as a result of problematic personality features of the couple. This view enables women, especially secular women who live in a community that openly places the values of partnership and equality between the genders as a central value, to distance the potential feeling of victimization (Drout \& Gaertner, 1994; Kristiansen \& Giuleitti, 1990). By distancing the victim or offender's characterizations, these women are able to 
preserve the perception that the kibbutz is the safest place from violence. Distancing potential victimization by relating the violence to the battered woman's features is consistent with the findings of Bogosh and Don-Yechiya (1999), which show that, in cases of violence within couples, female judges in Israel's magistrate's courts tend to give lighter verdicts than do male judges. The researchers' explanation of this is also related to the defensive technique of distancing the victim. They claim that the female judges who benefit from a high and prestigious position feel the need to distance themselves from women who are victims and prefer to assume that something in the victim's behavior was amiss.

Perceiving violence within a couple as a matter that kibbutz institutions should deal with rather than as a matter that should be dealt with by external supervising institutions such as the Department of Welfare or the police is embedded, as we saw in the introduction (Ben-Rafael, 1996; Sheffer \& Shapira, 1992), in the perception of internal supervision that characterizes closed communities such as the kibbutz community. Our hypothesis was that as the rate of closure of the community grows, so will the tendency to use internal supervising and enforcing mechanisms. Indeed, as we hypothesized, there is a significant difference between the two types of kibbutz life in the readiness to involve external supervising and enforcing institutions. Because of its special character, the religious kibbutz continues to preserve a higher level of commitment to the communal ideology and to the supervising institutes that preserve it. Therefore, it exhibits a stronger tendency to continue to use internal supervising mechanisms and to not involve the police in cases of violence between partners. Members of the religious kibbutz, especially the men, compared to the other participants, believe in leaving violence within the family a secret matter that belongs to the family alone. In this, they express the religious view that sees the preservation of the family framework as a highly sacred value. Compared to the religious kibbutz members, most of the members of the secular kibbutz, especially the women, do not believe that violent events within the family should be hidden, and they tend to agree with involving external enforcement systems when such an event occurs. Secular women, more than any other group in the sample, do not perceive themselves as committed to the kibbutz supervising system and the rules that guide it. They insist that external supervising systems be present.

This finding seems to contradict the former finding regarding the explanations of women to violence against women. It seems that the attitude of secular kibbutz women, compared with that of secular men or of male and female members of the religious kibbutz, expresses the greatest ambivalence. On one hand, secular female kibbutz members believe that because of the kibbutz's special characteristics there is almost no violence against women by their partners and that when such an event occurs, it is not a symptom of a social structure but a specific matter that is related to the unique features of the deviant or the victim. On the other hand, the secular women feel that they are not committed to preserving the closure and the inner bond that characterizes the kibbutz, making it possible to involve external supervising mechanisms if by chance an event of that sort occurs. Possibly, it 
is exactly this perception, which sees the violent event as a specific case that does not express a social problem, that enables the women to support the bringing in of external supervising mechanisms, as the violent event cannot be held to point to kibbutz society in general or to them as women specifically.

As was discussed in the introduction, the question as to who defines a situation or a behavior as a social problem, and when they do so, is not necessarily related to the actual level of the violent behavior but rather to the cultural perception of values by those who are involved in the process of definition. In fact, as can be seen in the section describing the results, the described level of domestic violence, as illustrated by the kibbutz domestic violence assistance groups, does not compare and is greater than the perceived notion of the level of violence by kibbutz members. According to the social construct theory, (Blumer, 1971) for a behavior to be given the meaning of a social problem, a collective definition must see it as a one and must as a result form a social policy and plan that is put into practice (Spector $\&$ Kitsuse, 1977). Changing the issue into a social or public problem means that there must be a certain group that has claims toward another group regarding a certain issue. This explanation sees the defining of a phenomenon as a social problem as an expression of the relative power of different groups in society and of the influence that they have on defining the reality of the problem. Bearing in mind that the various definitions are meant to preserve the economic and social systems of those involved in the process and taking into consideration the traditional perceptions in the kibbutz regarding declared equality between the genders and at the same time noticing the political weakness of women in the kibbutz, it would seem clear that the redefinition process of violence as a social problem is only at its initial stage in the kibbutz. In kibbutz society, perhaps in contrast to other parts of Israeli society, it is still hard to identify a process by which certain groups are committed to define this sort of deviation as a social problem with which it is important to deal publicly. As the claim is that women are equal to men, the demands to discuss equality between the sexes and the definition of violence within couples as a social problem become irrelevant and contrasting to the definitions of collective values of the kibbutz. If those requests are ever brought up, they are ignored or denied (Eilam, 1995). It seems that when the kibbutz has to deal with such deviation, defending the social cohesion in the kibbutz in general, and in the religious kibbutz in particular, becomes a central value. The social and cultural closure that in the past characterized the secular kibbutz and that still characterizes the religious kibbutz assists in preserving the perception of violence within a couple as a personal and mental problem of those involved. Perceiving violence as a personal problem and not as an expression of the social structure enables the members of the closed community to continue to hold on to the existing normative and cultural system without having to examine or change it.

Informal statistics (Gilboa, 2001) pointing to the existence of family violence within the kibbutz society on one hand, and the general tendency of kibbutz organizations to ignore or deny this problem in hope they will disappear on the other hand, make the involvement of law enforcement agencies, and the decision of 
how to take care of these problems, a matter that should not be left inside the kibbutz movement, religious or secular. The education and criminal justice systems need to create educational and preventative programs that target the kibbutz society and that raise the community's awareness of the problem. It is possible that the creation of volunteer organizations (as discussed at the beginning of this article) within the kibbutz suggests that the kibbutz movement is ready to start to address the problem of violent and sexual assaults within the family structure.

To pursue this end, there is need for further research that will examine the relation between cultural and social structure of the kibbutz and the preferred reactions of kibbutz members to violent behaviors generally and to domestic violence toward women in particular.

Understanding the process of changing attitudes toward domestic violence in closed communities such as the kibbutz can help us to intervene and assist in changing attitudes toward domestic violence in many other segregated communities. These communities share the desire not to face the problem of domestic violence as a social problem. Ignoring the problem might diminish the impact of national voluntary and formal organizations that were originally designed to assist and prevent domestic violence everywhere.

\section{REFERENCES}

Abulafia, Y. (1997). The process of creating a social construct of violence against women as a social problem in Israel. Unpublished master's thesis, Bar-Ilan University, Ramat-Gan, Israel.

Avivi, M. (1999). "Negative deployment" for dealing with drug abuse among adolescents in religious kibbutzim. Unpublished manuscript, Hebrew University, Jerusalem.

Becker, H. (1966). Social problems: A modern approach. New York: John Wiley.

Ben-Rafael, A. (1996). Not a total revolution. Ramat Efal, Israel: Yad Tabenkin.

Blanc, D. (1995). Women in kibbutz change processes in the 1990s. Ramat Efal, Israel: Yad Tabenkin.

Blumer, H.(1971). Social problems as collective behavior. Social Problems, 18, 298-306.

Bogosh, R., \& Don-Yechiya, R. (1999). The gender of justice: Bias against women in the Israeli courts. Jerusalem: The Jerusalem Institute for Israel Studies.

Chamallas, M. (1999). Introduction to legal studies. New York: Aspen Law \& Business.

Cullen, F. T. (1994). Social support as an organizing concept for criminology. Justice Quarterly, 11, 527-559.

Drout, C. E., \& Gaertner, S. L. (1994). Gender differences in reaction to female victims. Social Behavior and Personality, 22, 267-278.

Eilam, A. (1995). Rape in Israel: The raped woman and the authorities. Jerusalem: The Jerusalem Institute for Israeli Research.

Fogel-Biaggi, S., Sheffer, Y., \& Shapira, R. (1992). Kibbutz society: Continuity and change. Tel Aviv, Israel: Open University.

Gilboa, N. (2001). To break the silence. Retrieved June 26, 2004, from http://www.maariv.co.il

Golan, S. (1961). Kibbutz issues. Tel Aviv, Israel: Sifriyat Hapoalim.

Gusfield, J. (1981). The culture of public problems. Chicago: University of Chicago Press.

Hakins, J. D., Artur, M. W., \& Catalano, R. F. (1995). Preventing substance abuse. In T. Hirschi (Ed.), Causes of delinquency (pp. 343-427). Berkeley, CA: University of California Press.

Interoffice Committee on Domestic Violence. (2000). Jerusalem: Minster of Welfare. 
Izkovitz, Z., \& Gripel, A. (1998). Police treatment of domestic abuse in families and relationships. An evaluation research. Haifa, Israel: Haifa University.

Kamir, O. (2002). Feminism, rights and the law. Jerusalem: Ministry of Defense.

Kanter, R. M. (1972). Commitment and community, communes and utopias in sociological perspective. Cambridge, MA: Harvard University Press.

Kelly, H. H. (1971). Attribution in social interaction. Morristown, NJ: General Learning Press.

Kristiansen, C. M., \& Giulietti, R. (1990). Perceptions of wife abuse: Effects of gender, attitudes towards women, and just-world beliefs among college students. Psychology of Women Quarterly, 14, 177-189.

Larnner, M. S. (1980). The belief in a just world. New York: Plenum.

Lev-Ari, R., \& Yairi, D. (1996). You mustn't hit: Battered women in Israel. Tel Aviv, Israel: Keshet.

Mackinnon, C. (2001). Sex equality. New York: Foundation Press.

Palgi, M. (1993). Kibbutz women: Gender roles and status. Israel Science Research, 8(1), 108-121.

Rosalio, D. (1993). Changes in the kibbutz and kibbutz research: Theoretical aspects, 9. Ramat Efal, Israel: Yad Tabenkin.

Rosner, M., Glick, Y., \& Goldemberg, G. (1993). Value orientations and directions of change in the kibbutz. Israel Social Science Research, 8, 11-26.

Shaver, K. (1970). Defensive attribution. Journal of Personal Psychology, 14(2), 101-113.

Sheffer, Y., \& Shapira, R (1992). Kibbutz society: Continuity and change. Tel Aviv, Israel: Open University.

Shoham, E. (1995). Communal response to criminal behavior in the Kibbutz. Crime, Law and Social Change, 22, 149-161.

Shoham, E. (1996). The attitude of kibbutz youth to rape: Myth versus reality. International Journal of Offender Therapy and Comparative Criminology, 40(3), 212-223.

Shoham, E. (2000). The battered woman's perceptions of the characteristics of her encounter with the police. International Journal of Offender Therapy and Comparative Criminology, 44(2), 242-257.

Shoham, E., \& Abulafia, Y. (in press). Profiles of judicial decisions in cases of domestic violence in the Israeli magistrate's courts. Law \& Society Review.

Silver, V. (1984). Male and female did He create them: On sexual equality in the kibbutz. Ramat Efal, Israel: Yad Tabenkin.

Spector, M., \& Kitsuse, J. (1977). Constructing social problems. New York: Cummings.

Spiro, M. E. (1983). Is the family universal? The Israeli case. In E. Krousz (Ed.), The sociology of the kibbutz (pp. 239-250). London: Transaction Books.

Sugerman, D. B. (1994). The conception of rape: A multidimensional scaling approach. Journal of Social Behavior and Personality, 9, 389-408.

Vegshal, R. (2002). The conference on violence and sexual assault in the kibbutz. Retrieved June 24, 2004, from www.kibbutz.org.il/ishaqtkifa/021104.hatrad.htm

Weisburd, D., \& Britt, C. (2003). Statistics in criminal justice (2nd ed.). London: Thomson Wadsworth.

West, R. (1997). Caring for justice. New York: New York University Press.

Zamir, A. (1986). Mothers and daughters. Norwood, PA: Norwood Editions.

\section{Efrat Shoham, Ph.D.}

Senior Lecturer

Criminology Department

Ashkelon Academic College

Home address: Kibbutz Netzer Sereni, 70395

Israel 